\title{
TnA-directed Deletion of the trp Operon from RSF2124-trp in Escherichia coli
}

\author{
By HIROSHI TSUNEKAWA, * MASAKO TATEISHI, \\ TADAYUKI IMANAKA AND SHUICHI AIBA \\ Department of Fermentation Technology, Faculty of Engineering, Osaka University, \\ Yamada-kami, Suita-shi, Osaka, Japan
}

(Received 26 June 1980; revised 22 November 1980)

Plasmid pMT-trp was constructed by digestion of RSF2124-trp with restriction endonuclease PstI and ligation with T4 ligase. In pMT-trp about $78 \%$ of the DNA of transposon TnA from RSF2124-trp was deleted, and hence the gene for ampicillin resistance was lost. All Trp- segregants from pMT-trp carriers in Escherichia coli W3110 and its derivatives were found to have lost the entire plasmid. On the other hand, deletion plasmids which had lost the trp operon were found among $\operatorname{Trp}^{-}$segregants from RSF2124-trp carriers, particularly from the mutant strain $\operatorname{trp} A E 1 \operatorname{trpR} \operatorname{tnaA}$. The experimental fact that deletion occurred exclusively in RSF2124-trp suggests that the presence of TnA in the plasmid (RSF2124-trp) was responsible for the deletion.

\section{INTRODUCTION}

'Transposons' have been recognized as the translocatable elements that carry drugresistance gene(s) (Kleckner, 1977). It has been reported that transposons such as TnA (ampicillin resistance), Tn 10 (tetracycline resistance), etc. promote deletion of DNA in their immediate vicinity (Nisen et al., 1977; Holmans et al., 1978; Noel \& Ames, 1978; Tu \& Cohen, 1980).

Our previous work on the stability of the trp operon recombinant plasmid RSF2124-trp, which carries TnA, revealed many deletion plasmids amongst $\operatorname{Trp}^{-}$segregants (Imanaka et al., 1980). However, there are no reports in the literature on whether such deletion occurs if the transposon has been removed artificially from the plasmid. The purpose of this paper is to study the effect on plasmid stability of absence or presence of a transposon. Plasmids with deletions were examined by using restriction endonucleases to ascertain the whereabouts of the deletion.

\section{METHODS}

Materials. Ampicillin (Ap), chloramphenicol, agarose, lysozyme and RNAase A were purchased from Sigma. Pronase E was from Kaken Chemical Co., Tokyo, Japan. Restriction endonucleases (EcoRI, BamI, HindIII, and PstI), DNA of phage $\lambda$ and T4 ligase were purchased from Miles Laboratories, Elkhart, Ind., U.S.A. Bacto-tryptone was from Difco. All other reagents were purchased from Wako Pure Chemical Industries, Osaka, Japan.

Media and solutions. The complete medium (PBB) and the minimal medium (MM) used throughout were exactly the same as those described elsewhere (Imanaka et al., 1980). However, for the culture of pMT-trp carriers (for the preparation of pMT-trp, see below), Casamino acids in MM were adjusted to $5 \mathrm{~g} \mathrm{l}^{-1}$ instead of $0.5 \mathrm{~g} \mathrm{I}^{-1}$. The MM agar, Tryptone broth, TS buffer, TES buffer and Tris/borate buffer used were also as described previously (Imanaka et al., 1980).

Bacterial strains, plasmids and phages. Strains, plasmids and phages used in this work are listed in Table 1. 
Table 1. Strains of E. coli and plasmids and phages used

E. coli strain

C600-1

W3110

W3110

W3110

KM605

A 745
Relevant properties

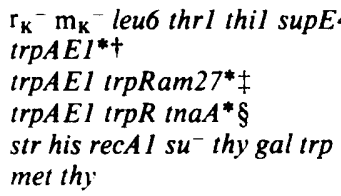

Plasmid

(RSF2 124-trp) (RSF2124-trp) (RSF2124-trp) (RSF2124-trp) $(\lambda d v 1)$

(ColE I)
Reference

Imanaka et al. (1980)

Imanaka et al. (1980)

Imanaka et al. (1980)

Imanaka et al. (1980)

Matsubara (1972)

Sakakibara \& Tomizawa

(1974)

\author{
Phage \\ $\lambda C I 90$ \\ $\lambda_{l_{2}{ }_{2}{ }_{1} r_{3}}$ \\ Reference \\ Kaiser (1957) \\ Ptashne \& Hopkins (1968) \\ *Isolated originally by C. Yanofsky. \\ + Deletion mutant of $\operatorname{trp} A-E$, designated AE1. \\ $\ddagger$ trp repressor amber mutant, designated $\mathrm{Ram}$. \\ $\S$ Tryptophanase-deficient mutant, designated Tna.
}

Plasmid construction and preparation. For construction of the specific plasmid designated pMT-trp, RSF2124-trp DNA in TS buffer was digested with restriction endonuclease PstI (for details of digestion. see below), followed by an elevation in temperature to $65^{\circ} \mathrm{C}$ for $10 \mathrm{~min}$ to inactivate PstI, and ligation with T4 ligase by the procedure of Tanaka \& Weisblum (1975). Escherichia coli W3110 trpAE1 cells were then transformed with the DNA solution by the method of Tanaka \& Weisblum (1975). Transformants ( $\operatorname{Trp}^{+}, \mathrm{Ap}^{\mathrm{s}}$ ) were selected by the procedure described previously (Imanaka et al., 1980).

Transformation of other $E$. coli cells also followed the method of Tanaka \& Weisblum (1975). DNAs of plasmids were purified by the method of Clewell (1972).

Phenotypic stability of plasmids. Phenotypic stability of RSF2124-trp and pMT-trp was tested by the procedure used previously (Imanaka et al., 1980), except that no drug was added to the preculture and subsequent culture media of pMT-trp carriers. Colicin E1 immunity and/or $\lambda$ immunity were tested, where necessary, as described by Imanaka et al. (1980).

Digestion of plasmid DNA with restriction endonucleases. Plasmid DNA (about $1 \mu \mathrm{g}$ ) in TS buffer was digested at $37^{\circ} \mathrm{C}$ for $1 \mathrm{~h}$ in each reaction mixture (total vol. $25 \mu \mathrm{l}$ ). The composition of the mixtures was as follows: (i) $1 \mu \mathrm{l}$ EcoRI, $10 \mathrm{~mm}-\mathrm{MgCl}_{2}, 50 \mathrm{~mm}-\mathrm{NaCl}, 10 \mathrm{~mm}$-Tris, pH 7.5; (ii) 2 to $3 \mu \mathrm{l} \mathrm{BamI,} 10 \mathrm{~mm}-\mathrm{MgCl}_{2}, 100 \mathrm{~mm}-\mathrm{Tr}$ is, pH 7.5; (iii) 2 to $3 \mu \mathrm{HindIII}, 6 \mathrm{mM}-\mathrm{MgCl}_{2}, 50 \mathrm{~mm}-\mathrm{NaCl}, 2.5 \mu \mathrm{g}$ bovine serum albumin, $6 \mathrm{~mm}$ - Tris, $\mathrm{pH} \mathrm{7.5;} \mathrm{(iv)} 2$ to

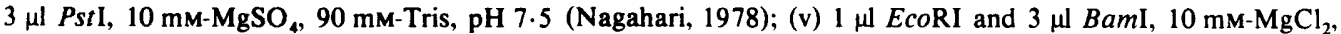
100 mM-Tris, pH 7.5.

Agarose gel electrophoresis of DNA. DNA samples were subjected to electrophoresis in agarose $\left(10 \mathrm{~g} \mathrm{1^{-1 } )}\right.$ dissolved in Tris/borate buffer as previously described (Imanaka et al., 1980). $\lambda$ DNA digested with EcoRI and/or Hindlll was used as an internal standard.

Preparation of crude extracts and assay of tryptophan synthase activity. Cells carrying RSF2124-trp and/or pMT-trp were grown until late exponential phase at $37^{\circ} \mathrm{C}$ in MM. Preparation of crude extract and assay of tryptophan synthase activity are described elsewhere (Smith \& Yanofsky, 1962; Imanaka et al., 1980). In parallel with the assay of tryptophan synthase activity, the phenotypic stability of RSF2124-trp and/or pMT-trp was assessed. The specific activity of tryptophan synthase was corrected by dividing by the fraction of Trp ${ }^{+}$cells in the stability test (Imanaka et al., 1980).

\title{
RESULTS \\ Restriction map of RSF2124-trp
}

The restriction map of the recombinant plasmid RSF2124-trp is shown in Fig. 1. The arrows inside and outside the circle indicate the cleavage sites, which were determined by reference to the results of other workers as well as our own work on each restriction endonuclease, i.e. EcoRI (E), HindIII (H), BamI (B) and PstI (P). The molecular sizes of the DNA fragments obtained with each restriction endonuclease are listed in Table 2. 


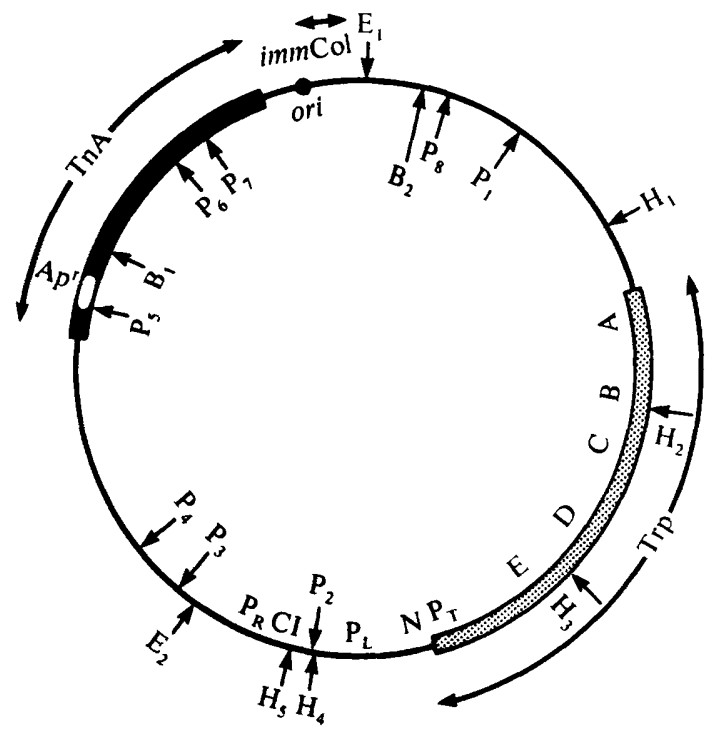

Fig. 1. Restriction map of RSF2124-trp. The arrows inside and outside the circle indicate the cleavage sites for restriction endonucleases EcoRI (E), HindIII (H), BamI (B) and PstI (P). Different cleavage sites for the same restriction endonuclease are distinguished by subscripts. The sizes of the DNA fragments are listed in Table 2. ori, replication origin; imm Col, colicin E1 immunity; A, B, C, D, E, structural genes of $E$. coli tryptophan (trp) operon; $\mathrm{P}_{\mathrm{T}}$, $\operatorname{trp}$ operon promoter; $\mathrm{N}, N$ gene; $\mathrm{P}_{\mathrm{L}}$, leftward promoter; $\mathrm{CI}, \lambda$ immunity; $\mathrm{P}_{\mathrm{R}}$, rightward promoter; $\mathrm{Ap}^{\top}$, ampicillin resistance gene.

Table 2. Sizes of DNA fragments obtained by restriction endonuclease cleavage of RSF2124-trp

The fragments are those shown in Fig. 1 (read clockwise).

$\begin{array}{cc}\text { DNA } & \text { Size } \\ \text { fragment } & \text { (Mdal) }\end{array}$

Reference

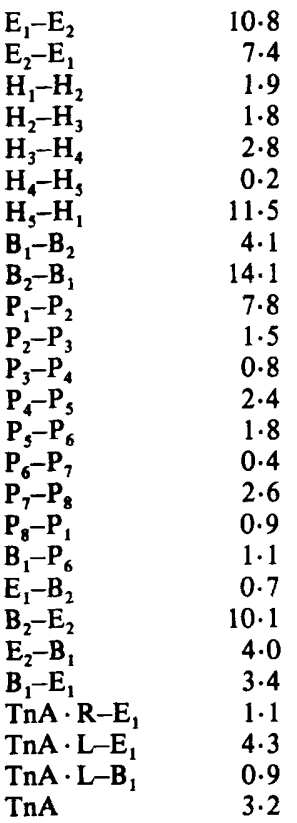

Nagahari et al. (1977)

This work (Fig. $5 k$ )

Nagahari (1978)

Nagahari (1978)

Nagahari (1978)

Nagahari (1978)

Nagahari et al. (1977); Nagahari (1978)

Heffron et al. (1977); Nagahari (1978)

Heffron et al. (1977); Nagahari (1978)

This work (Fig. 2a,5a); Nagahari (1978)

This work (Fig. 2a, 5a); Dougan et al. (1978); Nagahari (1978)

This work (Fig. 2a, 5a); Dougan et al. (1978)

This work (Fig. 2a, 5a); Collins \& Brüning (1978); Dougan et al. (1978)

This work (Fig. $2 a, 5 a)$; Collins \& Brüning $(1978)$

This work (Fig. 2a, 5a); Bukhari et al. (1977); Collins \& Brüning (1978)

This work (Fig. 2a, 5a); Bukhari et al. (1977); Smith et al. (1976)

This work (Fig. 2a, 5a); Nagahari (1978); Smith et al. (1976)

Collins \& Brüning (1978)

This work (Fig. $5 k$ )

This work (Fig. $5 k$ )

This work (Fig. $5 k$ )

This work (Fig. $5 k$ )

Dougan et al. (1978)

Dougan et al. (1978)

Heffron et al. (1977); Hoimans et al. (1978)

Heffron et al. (1977); So et al. (1975) 


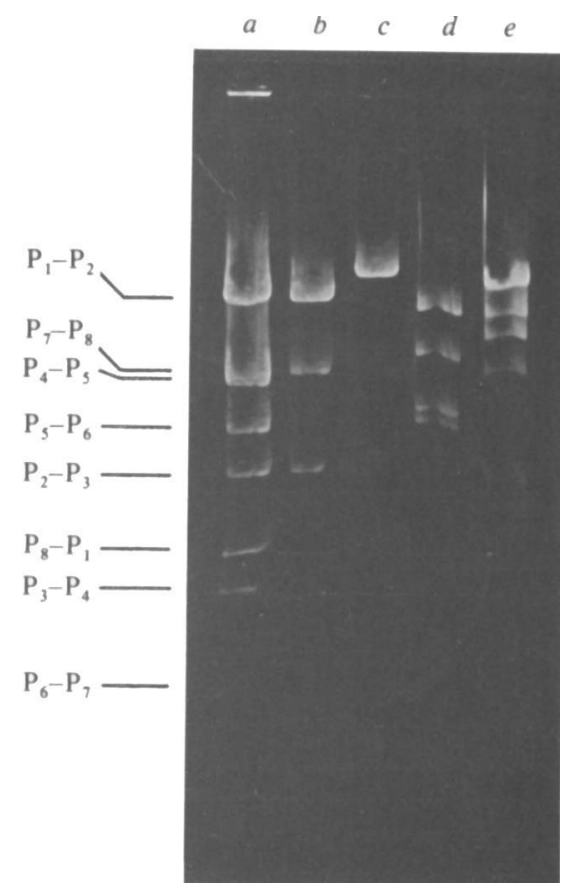

Fig. 2. Agarose gel electrophoresis of pMT-trp digested with restriction endonucleases. (a) Pstl digest of RSF2 124-trp (control); (b) Pst l digest: (c) Eco RI digest; (d) HindIII digest; (e) HindIII digest of $\lambda$ as reference. The sizes of the fragments in (e) are (from top) 14.9, 6.07. 4.13, 2.71, 1.42, 1.14 and $0.34 \mathrm{Mdal}$ (Bukhari et al., 1977) (the 0.34 Mdal fragment is not visible in the figure).

\section{Properties of pMT-trp}

The principal motive for constructing pMT-trp from RSF2124-trp, by digestion with Pst I followed by ligation with T4 ligase (see Methods and Fig. 1), was to obtain a plasmid to serve as a 'control' in this work. This plasmid, in which most of TnA is deleted, was needed because TnA has been confirmed by previous workers to promote the deletion of the plasmid carrying it (Nisen et al., 1977; Holmans et al., 1978; Tu \& Cohen, 1980). Plasmid pMT-trp was prepared such that the ampicillin resistance gene $\mathrm{Ap}^{\mathrm{r}}$ was deleted without impairing the $\operatorname{trp}$ operon on RSF2124-trp. Esche: ichia coli cells carrying pMT-trp were found to be imm $\lambda^{+}$and imm Col ${ }^{+}$.

Plasmid pMT-trp digested with PstI was analysed by agarose gel electrophoresis, with RSF2124-trp digested with the same restriction endonuclease included for reference (Fig. $2 a$, $b$ ). It is evident from Fig. $2(b)$ that three fragments of DNA, of 7.8, 2.6 and 1.5 megadaltons (Mdal), constitute pMT-trp. The largest fragment, $7.8 \mathrm{Mdal}$, originates from $\mathrm{P}_{1}$ to $\mathrm{P}_{2}$ on the restriction map of RSF2124-trp (see Fig. 1 and Table 2) and thus includes the trp operon. The second fragment, $2.6 \mathrm{Mdal}$, extends from $\mathrm{P}_{7}$ to $\mathrm{P}_{8}$, and contains the replication origin (ori) and $i m m$ Col. The last fragment, $1.5 \mathrm{Mdal}$, encompasses the region from $\mathrm{P}_{2}$ to $\mathrm{P}_{3}$, which carries the $\lambda C I$ gene $(\mathrm{imm} \lambda)$.

The digestion pattern of pMT-trp with EcoRI shows two fragments of DNA, of 10.9 and $1.0 \mathrm{Mdal}$ (Fig. $2 \mathrm{c}$ ). The DNA fragments from the digestion of pMT-trp with HindIII were of 5.2. $2.8,1.9,1.8$ and $0.2 \mathrm{Mdal}$ [Fig. $2 d$; the $0.2 \mathrm{Mdal}$ fragment is not clear, but this molecular size was taken from Nagahari (1978)]. The specific DNA fragment of $1.0 \mathrm{Mdal}$ appearing from the digestion with EcoRI, and the five fragments emerging from that with HindIII, yielded the restriction map of pMT-trp shown in Fig. 3. Note that trp genes A to E on the trp operon are reversed with reference to ori in comparison with their sequence in the RSF2124-trp restriction map (Fig. 1). 


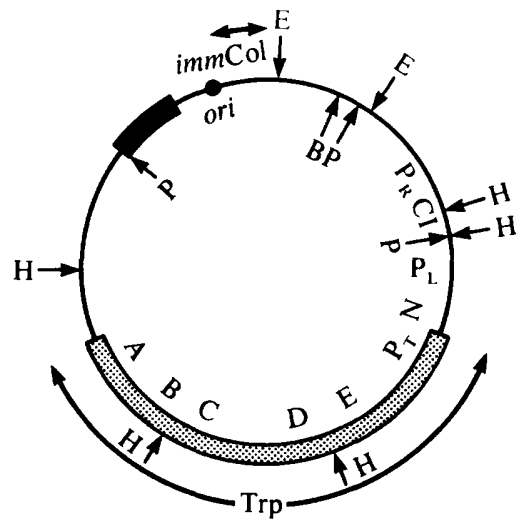

Fig. 3. Restriction map of pMT-trp. The arrows indicate the cleavage sites for restriction endonucleases EcoRI (E), HindIII (H), BamI (B) and PstI (P). Reading from ori clockwise on the map, the first P site represents ligation of $P_{8}$ and $P_{3}$ in Fig. 1; the second $P$ site is $P_{2}$ in situ; the third $P$ site represents ligation of $P_{7}$ and $P_{1}$. The abbreviations are explained in the legend to Fig. 1 .

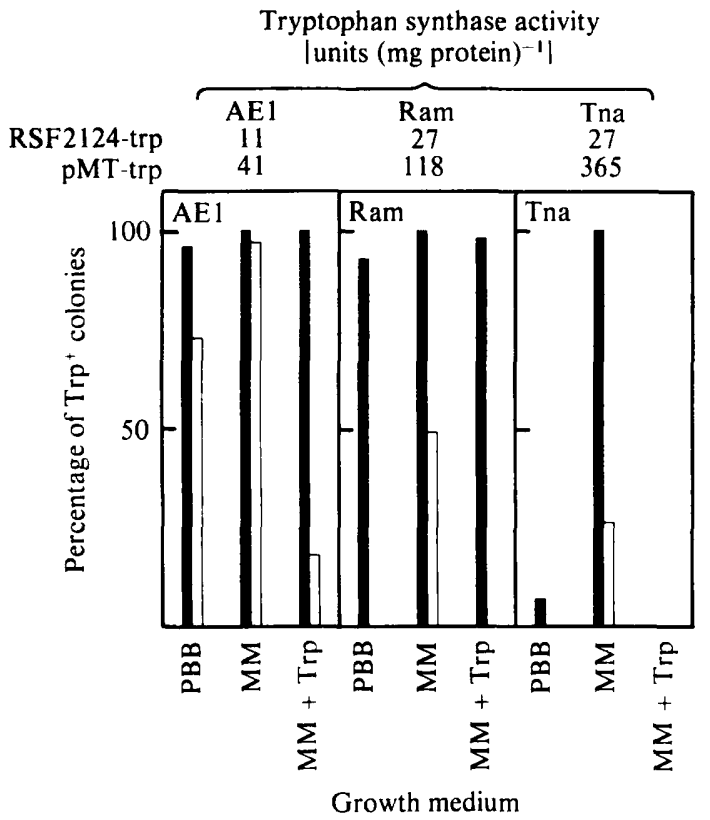

Fig. 4. Stability of recombinant plasmids and tryptophan synthase activity in mutants of $E$. coli W3110: $\operatorname{trp} A E 1$ (AE1), trpAE1 trpRam27 (Ram) and trpAE1 trpR tnaA (Tna). The fraction of colonies (100 scored for each experiment) exhibiting $\mathrm{Trp}^{+}$phenotype is shown in the histograms, for bacteria grown on each of three media (see text for details). Tryptophan synthase activity (tabulated above figure) was assayed with extracts from sonicated cells grown in MM. All the data for RSF2124-trp are reproduced from Imanaka et al. (1980). $\square$, RSF2124-trp; $\square$, pMT-trp.

\section{Phenotypic stability of RSF2124-trp and pMT-trp}

To study the phenotypic stability of RSF2124-trp and pMT-trp, E. coli W3110 trpAE1 (designated AE1), E. coli W3110 trpAE1 trpRam27 (designated Ram) and E. coli W3110 trpAE1 trpR tnaA (designated Tna), each harbouring one of the plasmids, were grown for 20 to 25 generations in PBB, MM or MM plus tryptophan $\left(50 \mu \mathrm{g} \mathrm{ml}^{-1}\right)$ and then plated on PBB agar. Colonies were then transferred to $\mathrm{MM}$ to score for $\mathrm{Trp}^{+}$phenotype. The percentages of 
colonies showing $\operatorname{Trp}^{+}$phenotype, and the tryptophan synthase activities of host cells carrying each plasmid, are shown in Fig. 4. (Since all the Trp ${ }^{+}$colonies of RSF2124-trp carriers were $\mathrm{Ap}^{\mathrm{r}}$, drug resistance is not shown on the ordinate of Fig. 4.) The tryptophan synthase activities of the bacteria carrying pMT-trp were 4 to 13 times greater than those of RSF2124-trp carriers. This high activity of tryptophan synthase seems plausible, since because there was no deletion of the trp operon in pMT-trp, whereas there was an appreciable deletion in RSF2124-trp (see below), the number of trp operons per chromosome may have been larger in pMT-trp carriers than in RSF2124-trp carriers. Our previous observation that phenotypic stability was inversely related to tryptophan synthase activity (Imanaka et al., 1980) was confirmed in the present study (see open bars in Fig. 4).

Immunity tests revealed that all $\operatorname{Trp}^{-}$segregants from pMT-trp carriers were imm $\lambda^{-}$ imm $\mathrm{Col}^{-}$, indicating that the plasmid had probably been lost; this was confirmed by the absence of plasmid covalently closed circular (CCC) DNA in CsCl-ethidium bromide density-gradient centrifugation analyses. $\mathrm{Trp}^{-}$segregants from RSF2124-trp carriers were either $\mathrm{Ap}^{\mathrm{r}}$ or $\mathrm{Ap}^{\mathrm{s}}$. Immunity tests of the $\mathrm{Trp}^{-} \mathrm{Ap}^{\mathrm{s}}$ segregants showed them to be imm $\lambda^{-}$ imm Col-; the disappearance of the plasmid was confirmed by $\mathrm{CsCl}$-ethidium bromide density-gradient centrifugation. Immunity tests of the $\mathrm{Trp}^{-} \mathrm{Ap}^{\mathrm{r}}$ segregants (about 300 in total) showed them to be almost exclusively imm $\lambda^{-} \mathrm{imm} \mathrm{Col}^{+}$, but exceptionally, one segregant was imm $\lambda^{+} \mathrm{immCol}^{+}$and another was imm $\lambda^{-} \mathrm{immCol}^{-}$. Plasmid CCC DNA could be extracted from all the $\operatorname{Trp}^{-} A p^{r} \mathrm{imm}^{+}{ }^{+} \mathrm{immCol}^{+}$or $\operatorname{Trp}^{-} \mathrm{Ap}^{\mathrm{r}} \mathrm{imm}^{-} \mathrm{immCol}^{+}$segregants, but not from the specific segregant $\operatorname{Trp}^{-} A p^{r}$ imm $\lambda^{-}$imm $^{-} \mathrm{Col}^{-}$. This segregant, harbouring no plasmid, may have had the TnA element translocated on to the bacterial chromosome.

\section{Digestion of deletion plasmids with restriction endonucleases}

Agarose gel electrophoresis showed that plasmid CCC DNAs extracted from $\mathrm{Trp}^{-} \mathrm{Ap}^{\mathrm{r}} \mathrm{immCol}^{+}$segregants were smaller than RSF2124-trp (results not shown). Accordingly, the plasmids were deletion mutants of RSF2124-trp. In contrast, no deletion plasmids were obtained from pMT-trp, from which most of the TnA element has been deleted (Fig. 3). It thus appears that the presence of TnA in RSF2124-trp was the main factor responsible for the appearance of deletion plasmids.

Several deletion plasmids were prepared from cultures of RSF2124-trp carriers in PBB medium in exactly the same fashion as in the stability test. Segregants ( $\operatorname{Trp}^{-} \mathrm{Ap}^{r}$ imm $\lambda^{-} \mathrm{immCol}^{+}$-with one exception: $\operatorname{Trp}^{-} \mathrm{Ap}^{\mathrm{r}} \mathrm{imm} \lambda^{+} \mathrm{immCol}^{+}$) gave various deletion plasmids. The results of agarose gel electrophoresis of RSF2124-trp and several deletion plasmids, all of which were digested with Pst I, are shown in Fig. 5 ( $a$ to $i$ ). Deletion plasmids were obtained from host bacteria of Tna, Ram and AE1 and designated $\Delta T, \Delta R$ and $\Delta \mathrm{A}$, respectively. The numbers in the $\Delta \mathrm{T}$ and $\Delta \mathrm{R}$ designations are the serial numbers of plasmids obtained from the same host strain. The deletion plasmid designated $\Delta \mathrm{C}$ was obtained from $E$. coli C600-1 carrying RSF2124-trp.

It can be seen from Fig. 5 that DNA fragments $P_{5}-P_{6}(1.8 \mathrm{Mdal})$ and $P_{6}-P_{7}(0.4 \mathrm{Mdal})$ are common to all the deletion plasmids. Except for $\Delta \mathrm{C}$ (Fig. 5i), another DNA fragment, $\mathrm{P}_{7}-\mathrm{P}_{8}$ (2.6 Mdal) could also be found in all the deletion plasmids. On the other hand, $P_{1}-P_{2}$ (7.8 Mdal) was apparently deleted in the deletion plasmids. Except for $\triangle \mathrm{R} 3$ (Fig. $5 \mathrm{~g}$ ), DNA fragments $\mathrm{P}_{2}-\mathrm{P}_{3}(1.5 \mathrm{Mdal}), \mathrm{P}_{3}-\mathrm{P}_{4}(0.8 \mathrm{Mdal})$ and $\mathrm{P}_{4}-\mathrm{P}_{5}(2.4 \mathrm{Mdal})$ were also deleted. It is difficult to distinguish $P_{7}-P_{8}(2.6 \mathrm{Mdal})$ from $P_{4}-P_{5}(2.4 \mathrm{Mdal})$ in Fig. 5 , but the deletion of $\mathrm{P}_{4}-\mathrm{P}_{3}$ was confirmed by the fact that all the deletion plasmids possessed the $\mathrm{E}_{1}$ cleavage site ( $\triangle R 3$ also possessed the $E_{2}$ cleavage site), and thus contained fragment $P_{7}-P_{8}$.

These observations on DNA fragments of deletion plasmids digested with Pst $\mathrm{I}$ can be summarized as follows: fragments $P_{5}-P_{6}$ and $P_{6}-P_{7}$ were present, while fragments $P_{5}-P_{4}$, $P_{4}-P_{3}, P_{3}-P_{2}$ and $P_{2}-P_{1}$ were absent (except for $\Delta R 3$ ) (see Fig. 1 and Table 2). Consequently, one of the deletion termini of the plasmids other than $\Delta R 3$ might have been between $P_{4}$ and $P_{5}$ sites, and that for $\Delta R 3$ between sites $P_{1}$ and $P_{2}$. 


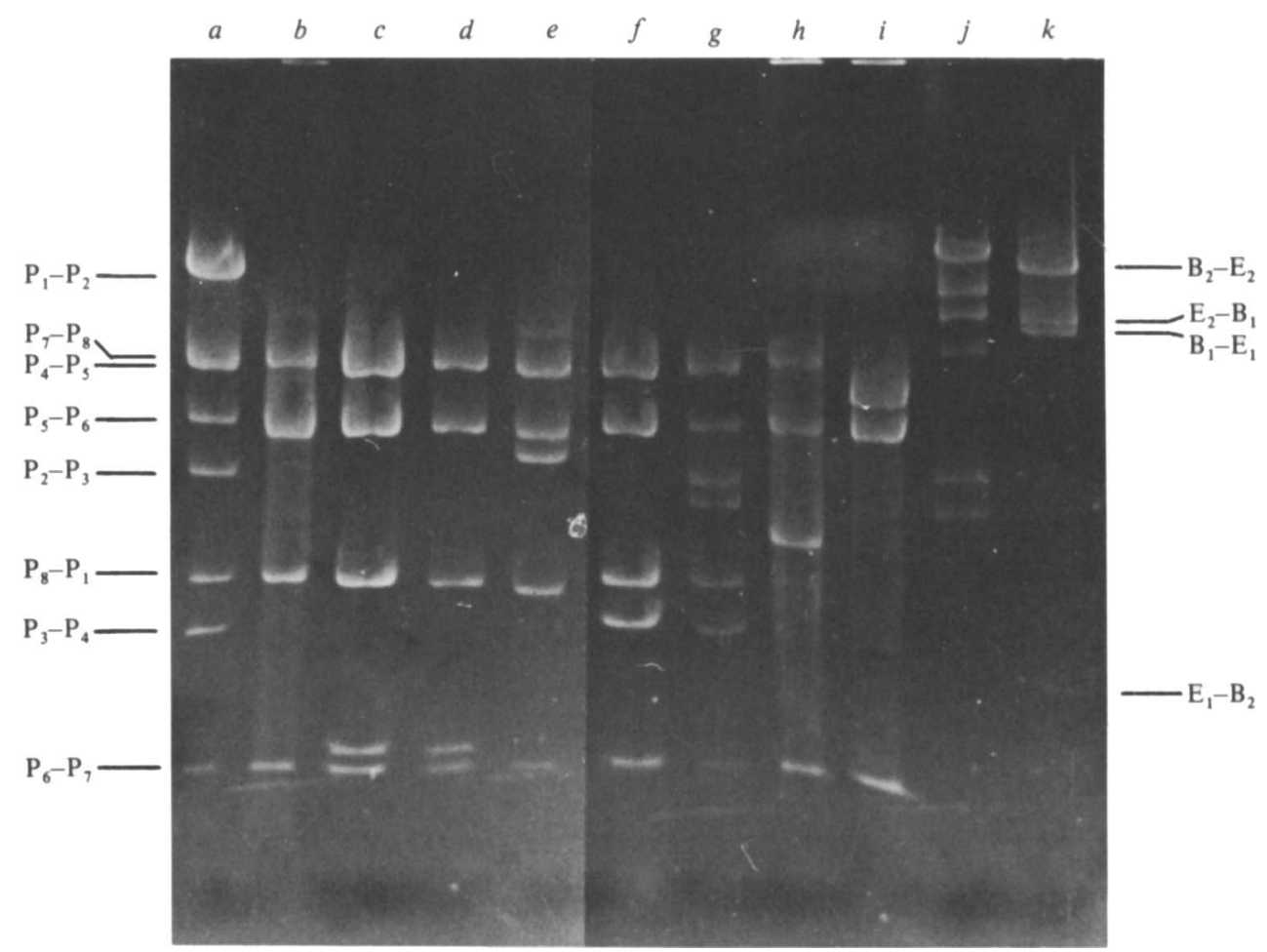

Fig. 5. Agarose gel electrophoresis of restriction endonuclease digests of RSF2124-trp and deletion plasmids derived from it. (a) PstI digest of RSF2124-trp. The sizes of the fragments are (from top) 7.8, 2.6, 2.4 (appearing as doublet), 1.8, 1.5, 0.9, 0.8 and $0.4 \mathrm{Mdal}$. (b) to (i) PstI digests of deletion plasmids $\Delta \mathrm{T} 1(b), \Delta \mathrm{T} 2(c), \Delta \mathrm{T} 3(d), \Delta \mathrm{R} 1(e), \Delta \mathrm{R} 2(f), \Delta \mathrm{R} 3(g), \Delta \mathrm{A}(h)$ and $\Delta \mathrm{C}(i)$. (Deletion plasmids designated $\Delta \mathrm{T}, \Delta \mathrm{R}, \Delta \mathrm{A}$ and $\Delta \mathrm{C}$ were obtained from host bacteria of $E$. coli Tna, Ram, AEl and $\mathrm{C} 600-1$, respectively. The numbers in the $\Delta \mathrm{T}$ and $\Delta \mathrm{R}$ designations are the serial numbers of plasmids from the same host strain.) $(j) H i n$ dIII digest of $\lambda$ (control). (k) EcoRI and BamI double digest of RSF2124-trp (used for Fig. 1 and Table 2 - the 7.4 Mdal fragment $E_{2}-E_{1}$ between $B_{2}-E_{2}$ and $E_{2}-B_{1}$ on the gel is not visible on the Figure).

A specific DNA fragment, not originally observed in RSF2124-trp when digested with PstI, emerged in the digests shown in Fig. $5(c, d, e, g, h, i)$. No new fragments seemed to appear in Pst I digests of $\Delta \mathrm{T} 1$ (Fig. $5 b$ ) or $\Delta \mathrm{R} 2$ (Fig. $5 f$ ). However, in the $\Delta \mathrm{T} 1$ digest, the $1.8 \mathrm{Mdal}$ DNA fragment appeared as a doublet; the original fragment, $\mathrm{P}_{5}-\mathrm{P}_{6}$, was superimposed on another fragment of $1.8 \mathrm{Mdal}$ that had been generated due to the deletion of DNA. In the $\Delta \mathrm{R} 2$ digest (Fig. $5 f$ ), the fragment corresponding to $\mathrm{P}_{3}-\mathrm{P}_{4}$ was different from that in the original plasmid RSF2124-trp (Fig. $5 a$ ). The difference was checked by digestion with BamI (results not shown).

To recapitulate, the deletion plasmids $\left(\mathrm{Ap}^{\mathrm{r}}\right)$ studied in this work had Pst $\mathrm{I}$ sites $\left(\mathrm{P}_{5}, \mathrm{P}_{6}\right.$ and $P_{7}$ ) (see Fig. 5) and an EcoRI site $\left(E_{1}\right)$ in common. These deletion plasmids ranged in size from $4.3 \mathrm{Mdal}(\Delta C)$ to $11.7 \mathrm{Mdal}(\Delta R 3)$. Since the DNA fragment from $E_{1}$ to $T n A \cdot L$ has been shown to be $4.3 \mathrm{Mdal}$ in size (Table 2), the fact that $\Delta \mathrm{C}$ was $4.3 \mathrm{Mdal}$ in size suggests that one of the deletion termini for $\Delta C$ is located next to $\operatorname{TnA} \cdot \mathrm{L}$.

\section{DISCUSSION}

Recently, keen attention has been paid to translocatable elements in prokaryotes (Kleckner, 1977). Holmans et al. (1978) observed that one of these translocatable elements, 


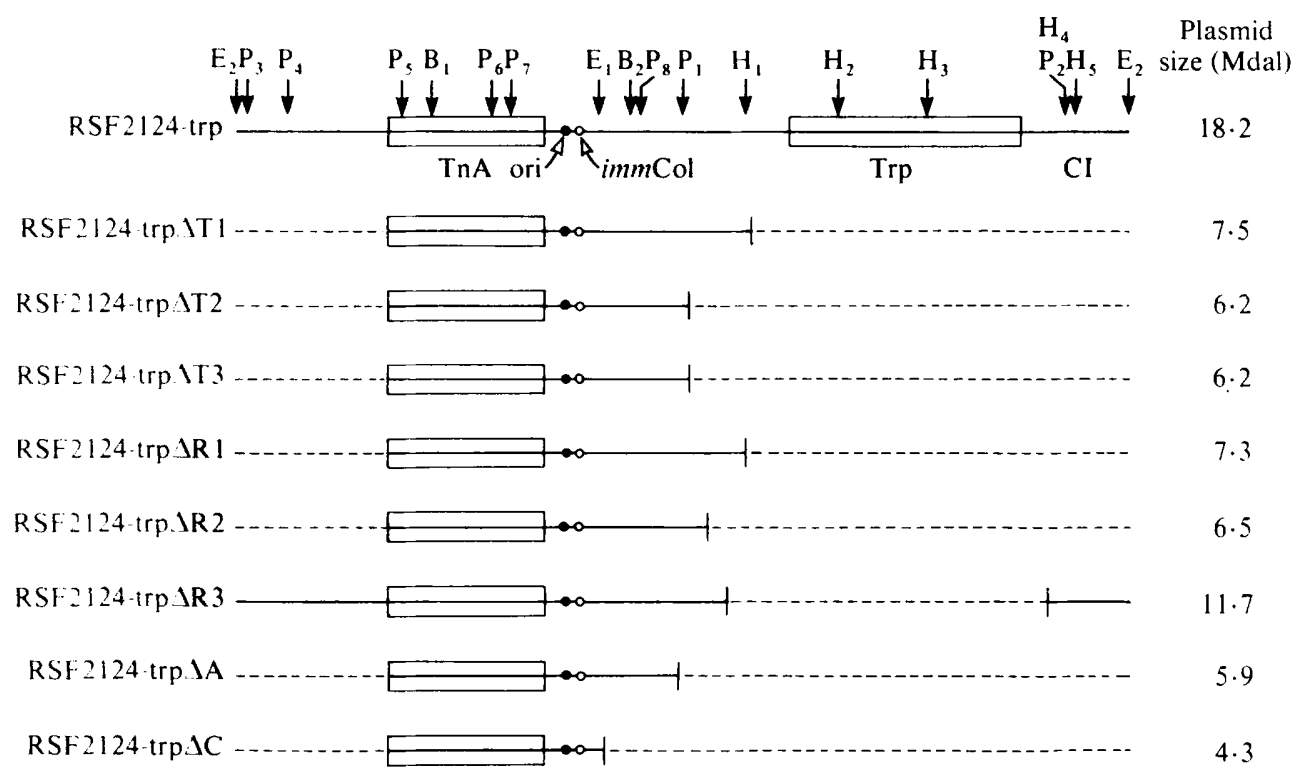

Fig. 6. Restriction maps of RSF2124-trp and deletion plasmids derived from it. The maps were constructed from digestions with EcoRI, BamI and PstI, followed by agarose gel electrophoresis. The deletions (indicated by the dashed lines), except for $\Delta R 3$, were postulated to occur at or next to the left terminus of TnA. The size of each plasmid (Mdal) is shown on the right of the figure.

TnA. which was harboured in a natural plasmid, R6K, could trigger the deletion of R6K. In addition, Nisen et al. (1977) reported that TnA caused the disappearance of a tetracycline resistance gene from $\mathrm{pSC} 105:: \mathrm{TnA}$.

We also observed the deletion of the trp operon from the recombinant plasmid RSF2124-trp. This deletion can be attributed to the effect of TnA, because such deletion did not occur in pMT-trp, which was prepared such that the TnA element was almost missing. All Trp ${ }^{-}$segregants from pMT-trp carriers (about 500 in total) were always accompanied by the imm $\lambda^{-}$immCol $^{-}$phenotype and no plasmid CCC DNA was detected in these segregants by $\mathrm{CsCl}$-ethidium bromide density-gradient centrifugation.

The frequency of deletion from the plasmid DNA of Trp ${ }^{-}$segregants was affected by the RSF 2124 -trp carrier host, being nearly $100 \%$ for Tna, $30 \%$ for Ram and $2 \%$ for AE 1 and C600-1. It is significant that the frequency of deletion showed a positive relationship with the tryptophan synthase activity of the host bacteria. As was discussed in our previous paper (Imanaka et al., 1980), the higher the activity of tryptophan synthase in the host bacteria, the more marked was the difference in growth rate between the cells carrying the Trp ${ }^{+}$ recombinant plasmid and those carrying the vector plasmid. In other words, a sort of 'enrichment' (Hershfield et al., 1974) took place during our experimental procedure. This is one of the reasons for the high percentage of deletions, especially in Tna, which exhibited high tryptophan synthase activity. To reiterate, two factors must be taken into account to clarify our experimental results: one, the presence of the TnA element in RSF2124-trp, and the other. the 'enrichment' of the segregant population that carries deletion plasmids. Gelfand et al. (1978) proposed a working hypothesis, in this connection, that deletion formation might be caused by a 'transposase' coded on TnA.

Referring to Figs 1 and 5, restriction maps of RSF2124-trp and the deletion plasmids derived from it were prepared (Fig. 6). In view of the fact that one of the deletion termini of these plasmids (except for $\Delta R 3$ ) was between the $P_{4}$ and $P_{5}$ sites, and also in the light of previous work on the possible deletion at the termini of TnA (Ohtsubo et al., 1979; Takeya et al.. 1979: Tu \& Cohen, 1980), the deletion was postulated here to occur at or next 
to the left terminus of TnA. The distinction between 'at' and 'next to' the terminus was beyond the scope of this work. DNA sequence analyses of various deletion plasmids to examine precisely the position of deletion are in progress.

It is interesting to reconfirm from Fig. 6 that several deletion plasmids appeared. However, $\Delta \mathrm{T} 2$ and $\Delta \mathrm{T} 3$ taken from the same batch of cultivation of (Tna) bacteria were exactly the same size (6.2 Mdal). $\Delta R 3\left(\operatorname{Trp}^{-} \mathrm{Ap}^{r} \mathrm{imm}^{+}{ }^{+} \mathrm{immCol}^{+}\right)$was exceptional among nearly 300 segregants: the other segregants were of $\operatorname{Trp}^{-} A p^{r}$ imm $\lambda^{-}$imm Col $^{+}$phenotype.

Technical assistance of T. Tanaka, Department of Fermentation Technology, Osaka University is appreciated. This work was partly supported by a grant-in-aid from the Education Ministry, Japanese Government.

\section{REFERENCES}

Bukhari, A. I., Shapiro, J. A. \& Adhya, S. L. (editors) (1977). DNA Insertion Elements, Plasmids, and Episomes, pp. 680 \& 713. New York: Cold Spring Harbor Laboratory.

Clewell, D. B. (1972). Nature of ColE1 plasmid replication in Escherichia coli in the presence of chloramphenicol. Journal of Bacteriology 110 , 667-676.

Collins, J. \& BRüning, H. J. (1978). Plasmids useable as gene-cloning vectors in an in vitro packaging by coliphage $\lambda$ : 'Cosmids'. Gene 4, 85-107.

Dougan, G., Saul, M., Warren, G. \& Sherratt, D. (1978). A functional map of plasmid ColE1. Molecular and General Genetics 158, 325-327.

Gelfand, D. H., ShePard, H. M., D'Farrell, P. H. \& Polisky, B. (1978). Isolation and characterization of a ColE1-derived plasmid copy-number mutant. Proceedings of the National Academy of Sciences of the United States of America 75, $5869-5873$.

Heffron, F., Bedinger, P., Champoux, J. J. \& FALKow, S. (1977). Deletion affecting the transposition of an antibiotic resistance gene. Proceedings of the National Academy of Sciences of the United States of America 74, 702-706.

HershField, V., BOYER, H. W., YANOFSKY, C., Lovett, M. A. \& Helinski, D. R. (1974). Plasmid ColE1 as a molecular vehicle for cloning and amplification of DNA. Proceedings of the National Academy of Sciences of the United States of America 71, 3455-3459.

holmans, P., Anderson, G. C. \& Clowes, R. C. (1978). TnA-directed deletions and translocations within the R6K plasmid. In Microbiology 1978, pp. 38-41. Edited by D. Schlessinger. Washington, D.C.: American Society for Microbiology.

Imanaka, T., TsUnekawa, H. \& Aiba, S. (1980). Phenotypic stability of trp operon recombinant plasmids in Escherichia coli. Journal of General Microbiology 118, 253-261.

KAISER, A. D. (1957). Mutations in a temperate bacteriophage affecting its ability to lysogenize Escherichia coli. Virology 3, 42-61.

KLECKNER, N. (1977). Translocatable elements in procaryotes. Cell 11, 11-23.

Matsubara, K. (1972). Plasmid formation from bacteriophage $\lambda$ as a result of interference by resident plasmid $\lambda d v$. Virology 47, 618-627.
NagahaRI, K. (1978). Deletion plasmids from the transformation of Pseudomonas aeruginosa trp cells with the RSF1010-trp hybrid plasmid and high levels of enzyme activity from the gene on the plasmid. Journal of Bacteriology 136, 312-317.

Nagaharı, K., Tanaka, T., Hishinuma, F., Kuroda, M. \& SAKAGUCHI, K. (1977). Control of tryptophan synthetase amplified by varying the numbers of composite plasmids in Escherichia coli cells. Gene 1, 141-152.

Nisen, P. D., Kopecko, D. J., Chou, J. \& Cohen, S. N. (1977). Site-specific DNA deletions occurring adjacent to the termini of a transposable ampicillin resistance element (Tn3). Journal of Molecular Biology 117, 975-998.

Noel, K. D. \& Ames, G. F. L. (1978). Evidence for a common mechanism for the insertion of the Tn 10 transposon and for the generation of Tn10-stimulated deletions. Molecular and General Genetics 166, 217-223.

OhtsuBo, H., Ohmori, H. \& Ohtsubo, E. (1979). Nucleotide-sequence analysis of Tn3 (Ap): implications for insertion and deletion. Cold Spring Harbor Symposia on Quantitative Biology 43, 1269-1277.

Ptashne, M. \& Hopkins, N. (1968). The operators controlled by the $\lambda$ phage repressor. Proceedings of the National Academy of Sciences of the United States of America 60, 1282-1287.

SaKakibara, Y. \& Tomizawa, J. (1974). Replication of colicin E1 plasmid DNA in cell extracts. Proceedings of the National Academy of Sciences of the United States of America 71, 802-806.

Smith, D. H. \& YanofSKy, C. (1962). Enzymes involved in the biosynthesis of tryptophan. Methods in Enzymology 5, 794-806.

Smith, D. L., Blattner, F. R. \& Davies, J. (1976). The isolation and partial characterization of a new restriction endonuclease from Providencia stuartii. Nucleic Acids Research 3, 343-353.

So, M., GILL, R. \& FALKow, S. (1975). The generation of a ColE1-Ap ${ }^{r}$ cloning vehicle which allows detection of inserted DNA. Molecular and General Genetics 142, 239-249.

Takeya, T., Nomiyama, H., Miyoshi, J., Shimada, K. \& TAKAGI, Y. (1979). DNA sequences of the integration sites and inverted repeated structure of transposon Tn3. Nucleic Acids Research 6, 18311841 . 

TANAKA, T. \& Weisblum, B. (1975). Construction of
a colicin E1-R factor composite plasmid in vitro: means for amplification of deoxyribonucleic acid.

Tu, C.-P. D. \& Cohen, S. N. (1980). Effect of DNA sequences adjacent to the termini of $\operatorname{Tn} 3$ on sequential translocation. Molecular and General Journal of Bacteriology 121, 345-362. 